\title{
Exploring the Success Factors of Customer Relationship Management (CRM) Systems in the Telecommunication Sector in Saudi Arabia
}

\author{
Sara A. Al-Rashed
}

\begin{abstract}
The telecommunication sector in Saudi Arabia is continuously seeking to build close relationships with its customers. It knows that its loyal customers are the source of most of its profit. With recent advances in technology, most telecommunication companies have customer relationship management (CRM) systems. However, implementing CRM systems has a low success rate. The implementation of a CRM system is a complex process, full of problems that must be managed properly to achieve the desired result. Otherwise, it could lead to a waste of time, effort and money as well as to an insufficient system. To eliminate these issues, this study aims to investigate the relationships among knowledge management, technology and CRM vision for successful CRM systems in the telecommunication sector in Saudi Arabia. The sample of this study included employees and managers employed in the Saudi telecommunication sector. SPSS and confirmatory factor analysis (CFA) were used. Out of 160 questionnaires, 143 were returned by the end of April 2016. Each variable was measured using reliable developed scales: successful CRM systems (three items), knowledge management (seven items), technology (four items) and CRM vision (three items). Data were input into SPSS and analysed using CFA. The results indicated that the hypotheses (H1, $\mathrm{H} 2$ and $\mathrm{H3})$ of this study were acceptable and supported.
\end{abstract}

Index Terms-Knowledge management, technology, successful CRM systems, CRM vision, telecommunication.

\section{INTRODUCTION}

Saudi Telecom Company (STC) provides modern services and products in different fields of the telecommunication industry, including mobile services, landlines, the internet and business solutions. The presented paper selected STC to investigate successful customer relationship management (CRM) factors. Many reasons exist for selecting STC. First, STC is the largest telecommunication services provider in the Middle East and North Africa. It is the leading operator within the Kingdom of Saudi Arabia, and its international presence extends to nine countries. In addition, STC has the highest and largest market capitalisation among other telecom companies. The subscribed market share for STC in Saudi Arabia is $44.4 \%$ [1]. STC was the first telecom communication company in Saudi Arabia that provided mobile and landline services, and STC is considered one of

Manuscript received August 2, 2016; revised February 23, 2017. This work was supported in part by AL-Imam Muhammad bn Saud Islamic University; Saudi Arabia.

Sara A. Al-Rashed is with the Department of Information System with AL-Imam Muhammad bn Saud Islamic University, Riyadh, Saudi Arabia (e-mail: sara@ccis.imamu.edu.sa). the largest public sector companies in Saudi Arabia. Furthermore, STC is the most popular telecommunication company in Saudi Arabia [2].

In the modern business era, CRM has become a critical part of marketing due to its ability to increase profits, enhance customer loyalty and improve customer retention. CRM also plays an important role in the activities of organisations, and while it can be defined in many ways, little consistency exists between those definitions.

Reference [3] described CRM as a tool that uses specific strategies, such as systems-oriented methods, technology that assists marketing relationships, business practices that aim to increase customer profitability and business models that focus on customer service or the establishment of win/win relationships between customers and a company's employees. By comparison, [4] believed that CRM could be employed as a viable strategy for businesses that function through tools and software designed to help companies to effectively manage and facilitate communication channels with their customers.

CRM can contribute to improving customer responsiveness, growing revenue and helping a company to capture a competitive advantage. However, while both the success and failure rates of CRM implementation are described in the existing literature, a high failure rate is associated with the implementation of CRM systems [5], [6]. In addition, [6] estimated CRM project implementation fails between $60 \%$ and $80 \%$ of the time.

Successful CRM implementation depends strongly on identifying and employing what are called critical success factors (CSF). CSF can be defined as "an area where things must be right for the business to flourish" [7]. This study will help to address the failure in implementing CRM systems by investigating the relationships among knowledge management, technology and CRM vision for successful CRM systems in the telecommunication sector in Saudi Arabia.

\section{LITERATURE REVIEW}

\section{A. Successful CRM System}

The successful implementation of a CRM system can play an essential role in an organisation's strategic position. CRM success assists in keeping customers and makes them more loyal. In other words, the successful implementation of a CRM system will benefit organisations by increasing customer profitability and attracting additional consumers [8]. The first critical goal during the development of a CRM 
platform is to identify a company's definition of CRM success. Reference [7] observed that the implementation of a CRM system is considered successful when it assists its company in meeting its business goals. These may involve multiple and varied goals, consisting of marketing goals, such as the loyalty, retention, acquisition and satisfaction of customers, and financial goals, such as increased profits and reduced costs.

Customer loyalty means that the most profitable customers communicate continuously with the organisation. Such loyalty represents their belief that the company's services and/or products are their best options and that the company has the correct services or products at the right time, place and price [8]. Customer satisfaction can be defined as a response or a feeling of satisfaction towards the experience of using a company product or service. Various researchers, including [9], [10] have used customer satisfaction as a measure of CRM system success. The profitability represents the deduction of organisations from all revenues and the offer of services or goods to their customers over a specific time period [11].

\section{B. Knowledge Management}

Generally, knowledge is an essential variable and is a source of competitive advantage for an organisation. As such, it has an essential role in the success of modern businesses. Knowledge management (KM) is a main research concern within the academic community as well, as it is considered one of the main factors for which companies allocate extra financial resources. Knowledge management permits organisations to access the specialised experiences and knowledge of employees to make improvements, generate new capabilities and enhance functional efficiency [12]. Knowledge management includes the generation of new knowledge produced following the explanation, distribution and use of existing knowledge, as well as the conservation and modification of existing knowledge. Knowledge management is a goal of any organisation seeking to generate and enhance its knowledge resources. It mainly requires the related activities of the association, identification and generation of knowledge. The success of any organisation thus depends on creating and developing knowledge resources [13].

Knowledge management can be defined as a company's ability to capture, manage and deliver valid, real-time product and service information with the goals of enhancing customer response and enabling faster decision-making based on reliable, real-time and accurate information [14]. Knowledge management is one of the major interests of the contemporary corporate culture worldwide, and many companies have incorporated knowledge management into their plans. According to [15], CRM systems should manage knowledge related to customers with the goals of improving service to and increasing the corporate understanding of clients. Likewise, [16] explained that a CRM system is related to the elements of knowledge management. Therefore, efficient and continuously updated knowledge about customers is vital to the successful introduction of CRM systems. Customer knowledge is highly valuable to both companies and their CRM systems [17]. Although research is limited on the specific impact of knowledge management on successful CRM systems, the exploration of the following hypothesis may produce useful information for resolving this particular issue. Therefore, the researcher has proposed the following:

H1. Knowledge management significantly and positively influences successful CRM implementation.

\section{Technology}

Managers know that customers are at the centre of business and that the success of their companies depend on them. Since telecommunication companies generally have large customer bases, it can be a challenge for these companies to ensure individual customer satisfaction. Loyal customers expect the best service, and ideally, technology can meet this challenge. However, if a company lacks an appropriate infrastructure, technology can present a major obstacle to the implementation of CRM systems. Several studies, including [18], [19], have mentioned that when technology is used incorrectly, CRM systems are more likely to fail.

The technology factor represents a collection of corporate resources that permit an organisation to save, utilise, collect and organise data about its customers [20]. Effective technology enables employees who engage with CRM systems to save, gather and categorise important data for and about their customers. By using information technology (IT), which offers an enhanced view of customer performance, organisations can develop enhanced relationships with their customers [20]. Technology can assist CRM systems in a variety of ways. For instance, it can aid in the identification of customer behaviour and streamline the collection, processing and management of customer data [21]. Furthermore, the use of appropriate technology can facilitate communication between customers and companies, resulting in the development of new working methods and increased customer satisfaction. As mentioned earlier, technology can also be used to conduct statistical analyses that effectively leverage operational efforts to invest in CRM [22].

Technology within a CRM system should first be employed by creating a customer database that contains an infrastructure of customer information; this process can help to facilitate the overall development of the CRM framework. Numerous technologies can be used during the development of CRM systems, such as data mining, analytical processing and data warehouse querying and reporting. Data mining plays a vital role during the implementation of CRM platforms because it allows employees to efficiently collect and identify data related to customer relationship [5]. Data warehousing's role is similarly significant because it enables customer data to be merged, managed, correlated and transformed into forms and formats that allow for the easy analysis and identification of customer behaviour. By using technology, a company can combine its customer information into an up-to-date and comprehensive database [19], [23]. Given that technology is regarded as one of the main components of CRM system [24], the role of technology is widely accepted in the literature, and technology issues have been reported as being among the causes of CRM failure [21]. Technology is a variable 
explored in this study. Therefore, the researcher has proposed the following:

H2. Technology significantly and positively influences successful CRM implementation.

\section{CRM Vision}

When implementing a CRM system, vision plays a critical role, as it allows stakeholders to communicate and share an interpretation of the system's essential features. CRM vision can be defined as the personality of any organization; vision creates a clear image for customers concerning company products, services and offers. The vision represents how the business wants its customers to feel and think about it [25].

According to [26], CRM implementation sometimes fails because ambiguity in the CRM vision exists; the plan for introducing and managing the system is not clear or well considered. For a CRM system to succeed, top managers need a strong, defined CRM vision and need to share it with employees, thereby encouraging them to activate their own CRM vision [10] . CRM vision is a variable explored in this study. Therefore, the researcher has proposed the following:

H3. CRM vision significantly and positively influences successful CRM implementation.

Thus, the model of this study consists of four variables, which are CRM vision, knowledge management and technology CRM as independent variables and successful CRM systems as a dependent variable in the telecommunication sector in Saudi Arabia as shown in Fig. 1.

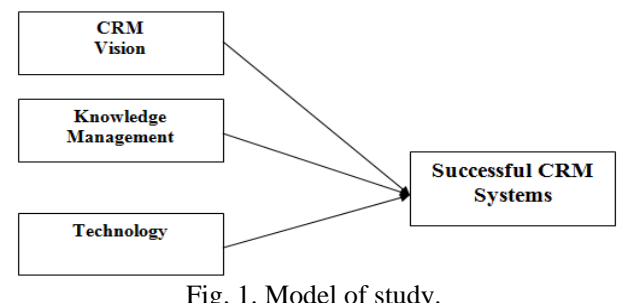

\section{Methodology}

This study chose a systematic random sample in which 160 respondents were identified from 15 places in the communication sector in the middle region of Saudi Arabia. The sampling frame for this study consisted of employees and managers who worked in the communication sector in Saudi Arabia in the period from April 20, 2016, to May 20, 2016. Out of the 160 questionnaires distributed, eight were undelivered, and nine questionnaires were incomplete (missing responses). Thus, a total of 143 responses were usable and used for subsequent analysis, giving a response rate of $89.3 \%$.

The questionnaire is divided into: (1) demographic variables (one item); (2) CRM vision (three items) adapted by [10], [19], [26]; (3) knowledge management (seven items) adapted by [10], [23]; (4) technology (four items) by [10], [23] ; and (5) successful CRM systems (three items) by [9], [10], [23] .

\section{A. Demographic Profile of the Respondents}

The survey sample for this research was the population. The survey was distributed to all employees and branch managers in the 15 STC branches. The sample size was 143 employees and managers. The following table, Table I, features the characteristics of the survey sample according to the job title. Based on Table 1, 143 participants of the sample study, representing a rate of $90.2 \%$, were employees, who constituted the largest group of the study sample, while 14 of the participants, representing a rate of $9.8 \%$, were managers, who made up the smallest category of the study sample.

TABLE I: THE DISTRIBUTION OF RESPONDENTS

\begin{tabular}{cll}
\hline \hline $\begin{array}{c}\text { Current } \\
\text { position }\end{array}$ & Frequency & Percent \\
\hline Employee & 129 & $90.2 \%$ \\
Manager & 14 & $9.2 \%$ \\
Total & 143 & $100 \%$ \\
\hline \hline
\end{tabular}

\section{B. Descriptive Analysis of Variables}

Descriptive analysis was conducted after the validity and reliability processes to ascertain the main score and standard deviation for the constructs. Based on the 143 valid cases being analysed in terms of the mean and standard deviation for all of the variables, CRM vision is represented by three items. Apparently, as shown in Table 2, the mean scores of this variable is considered very high (5.428). In addition, the results in Table II show relatively moderate mean scores for technology (5.075) and knowledge management (4.812). Finally, the mean score for successful CRM systems is (5.014).

\section{Reliability Test}

The research framework consists of three independent variables (CRM vision, knowledge management and technology) and one dependent variable (successful CRM systems) (see Table 2). Each construct shows Cronbach alpha readings of acceptable values of above 0.70 [27]. The reliability values for all constructs range from .74 to .87 . This indicates that all constructs have acceptable internal consistency.

\section{TABLE II: DESCRIPTIVE STATISTICS OF VARIABLES}

\begin{tabular}{llllll}
\hline Construct & $\begin{array}{l}\text { Original } \\
\text { Items }\end{array}$ & $\begin{array}{c}\text { Total } \\
\text { Mean }\end{array}$ & $\begin{array}{l}\text { Standard } \\
\text { Deviation }\end{array}$ & $\begin{array}{c}\text { Items } \\
\text { after } \\
\text { CFA }\end{array}$ & $\begin{array}{l}\text { Cronbach } \\
\text { Alpha after } \\
\text { CFA }\end{array}$ \\
\hline \hline $\begin{array}{l}\text { CRM vision } \\
\text { Knowledge } \\
\text { management }\end{array}$ & 3 & 5.428 & .813 & 3 & .747 \\
$\begin{array}{l}\text { Technology } \\
\text { Successful }\end{array}$ & 6 & 4.812 & .768 & 7 & .87 \\
$\begin{array}{l}\text { CRM } \\
\text { systems }\end{array}$ & 3 & 5.075 & .773 & 4 & .82 \\
\multicolumn{1}{c}{ Total } & 16 & 5.014 & .813 & 3 & .79 \\
\hline \hline
\end{tabular}

\section{CFA Results}

Table III shows that the confirmatory factor analysis (CFA) results. The researcher observed that the factor loadings of all observed variables or items are adequate, ranging from 0.57 to 0.81 . In this study, the 'cut-off' point chosen for 
significant loading is 0.50 , the minimum level required for a sample size of 120 and above as suggested by [27].

This indicates that all of the constructs conform to the construct validity test. As shown in Table III, the remaining numbers of items for each construct are as follows: CRM vision (three items) knowledge management (seven items), technology (four items), and successful CRM systems (three items), and the total of remaining items are 17.

TABLE III: FINAL CFA RESULTS OF CONSTRUCT VARIABLES

\begin{tabular}{|c|c|c|}
\hline Variable Name & Items after CFA & $\begin{array}{l}\text { Estimate (Factor } \\
\text { Loading) }\end{array}$ \\
\hline CRM vision & VS3 & .571 \\
\hline CRM vision & VS2 & .743 \\
\hline CRM vision & VS1 & .806 \\
\hline Knowledge management & KM7 & .611 \\
\hline Knowledge management & KM6 & .768 \\
\hline Knowledge management & KM5 & .735 \\
\hline Knowledge management & KM4 & .808 \\
\hline Knowledge management & KM3 & .781 \\
\hline Knowledge management & KM2 & .580 \\
\hline Knowledge management & KM1 & .701 \\
\hline Technology & $\mathrm{TCH} 4$ & .611 \\
\hline Technology & $\mathrm{TCH} 3$ & .794 \\
\hline Technology & $\mathrm{TCH} 2$ & .794 \\
\hline Technology & $\mathrm{TCH} 1$ & .760 \\
\hline CRM success & SUC3 & .674 \\
\hline CRM success & SUC2 & .810 \\
\hline CRM success & SUC1 & .768 \\
\hline Total items remaining & 17 & \\
\hline
\end{tabular}

\section{E. Hypotheses Results}

The number as shown in the Table IV hypothesized model did achieve model fit $(p<.001)$. Hence, the explanation of the hypothesis result is based on a simple regression result by SPSS version 17.0. Based on the finding, according to Table 4 , three hypotheses are significant through $\mathrm{t}$ values and are acceptable because the value of $t$ is above $+/-1.96(\mathrm{H} 1, \mathrm{H} 2$ and H3).

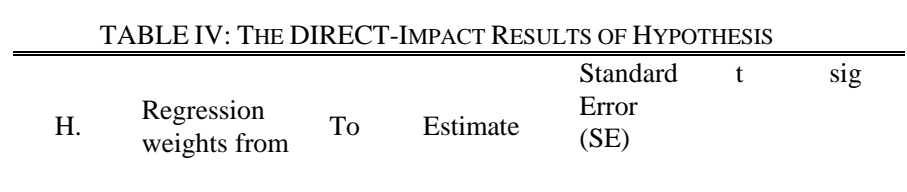

\begin{tabular}{|c|c|c|c|c|c|c|}
\hline H1 & KM & SUC & .402 & .06 & 9.82 & $\overline{c .000}$ \\
\hline $\mathrm{H} 2$ & TEC & SUC & .52 & .06 & 12.6 & .000 \\
\hline H3 & VS & SUC & .103 & .07 & 4.24 & .000 \\
\hline
\end{tabular}

\section{DISCUSSION}

As mentioned earlier, the results of this study attempt to examine the goodness of fit of the hypothesised structural model by integrating CRM vision, knowledge management and technology for successful CRM systems in the telecommunication sector in Saudi Arabia. As shown in Table IV, the hypothesised model achieves model fit ( $p$-value $=0.000, p<0.001)$. This implies that the hypothesised model is supported. Knowledge management was found to have a direct significant impact on successful CRM systems. Past studies have obtained similar result [9], [10], [28], [29] . Thus, a positive relationship between knowledge management and successful CRM systems means that the respondents have positive satisfied towards CRM systems in the telecommunication sector in Saudi Arabia in the future.

Second, technology has a direct positive effect on successful CRM systems in the telecommunication sector in Saudi Arabia; past studies have obtained a similar result [9], [24], [30]. Thus, a positive and significant impact exists in the relationship between technology and successful CRM systems in the telecommunication sector in Saudi Arabia. In addition, the respondents gave more attention to the relationship between technology and successful CRM systems in the telecommunication sector in Saudi Arabia.

CRM vision was found to have a direct significant impact on successful CRM systems. Past studies have obtained a similar result [23], [26], [30]. Thus, a positive relationship exists between CRM vision and successful CRM systems.

\section{Suggestion FOR Future RESARCH}

The sample of this study focused on the middle region of Saudi Arabia. However, future research should investigate the model in a different setting in Saudi Arabia, such as in the northern region. Therefore, more research needs to be done on these areas to measure and investigate international employees' satisfaction and loyalty in different countries. Other determinant factors need to be considered in future research, such as organizational factors (i.e. training), top-management support, environment factors and infrastructure factors. More importantly, the Ministry of Saudi Arabia should focus more on the employees and managers' satisfaction, the availability of modern facilities and the development of better transportation avenues that could help employees and managers to have faster access to all customer sites. Subsequently, it will lead to the augmentation of employees' and managers' satisfaction in the workplace.

\section{CONCLUSION}

The study examined some of the critical success factors of successful CRM systems in the telecommunication sector in Saudi Arabia. Three direct paths are found to be significant in relation to successful CRM systems in the telecommunication sector in Saudi Arabia: CRM vision, knowledge management and technology. Technology can increase the success of CRM by 52.8\%. Furthermore, knowledge management can increase the success of CRM by $40.2 \%$. Finally, CRM vision can increase the success of CRM systems by $10.7 \%$. 


\section{REFERENCES}

[1] GlobalComms Database Unitel (formerly Star Telecom Company), Riyadh, 2014.

[2] R. B. Sharma, "Customers satisfaction in telecom sector in Saudi Arabia: An empirical investigation," Eur. J. Mark., vol. 10, no. 13, pp. 354-363, 2014.

[3] C. G. Miller, "Customer relationship management implementation: A case study in the construction sector," Business School, University of Glamorgan, Pontypridd, 2007, pp. 1-10.

[4] M. B. Nejad, "Customer relationship management and its implementation in e-commerce," Int. J. Comput. Sci. Inf. Secur., vol. 9, no. 9, pp. 86-91, 2011.

[5] Y.-T. Wu, "Applying the strategic approach to assess customer relationship management," Int. J. Organ. Innov., vol. 2, no. 3, pp. 186-206, 2010.

[6] S. S. Miri-Nargesi, A. Keramati, H. Haleh, and A. Ansarinejad, "Assessing organizational readiness to customer relationship management using fuzzy analytical network process: A case study," Int. J. Acad. Res., vol. 3, no. 3, pp. 409-418, 2011.

[7] S. Al-Hudhaif, "The critical success factors for implementation of customer relationship management in the banking sector of Saudi Arabia," J. Glob. Bus. Manag., vol. 7, no. 1, pp. 1-7, 2011.

[8] S. Jayashree, S. Shojaee, and S. Pahlavanzadeh, "A critical analysis of customer relationship management from strategic perspective," in Proc. International Conference on e-Business, Management and Economics (ICEME), 2011, pp. 340-345.

[9] M. T. Küçükoğlu and R. İ. Pınar, "Effect of CRM's critical success factors on company performance," Manag. Stud., vol. 3, no. 1, pp. 41-49, 2015

[10] A. Garrido-Moreno and A. Padilla-Meléndez, "Analyzing the impact of knowledge management on CRM success: The mediating effects of organizational factors," Int. J. Inf. Manage., vol. 31, no. 5, pp. 437-444, 2011.

[11] I. Gordon, Managing the New Customer Relationship: Strategies to Engage the Social Customer and Build Lasting Value, John Wiley \& Sons, 2013.

[12] M. Alavi and D. E. Leidner, "Review: Knowledge management and knowledge management systems: Conceptual foundations and research issues," MIS Q., vol. 25, no. 1, pp. 107-136, 2001.

[13] R. Momeni and M. Taherkhani, "Analyzing knowledge management on success of customer relationship management considering organizational factors as mediatory variables (case study: Central Departments of Bank Saderat of Tehran)," Int. J. Manag. Humanit. Sci., vol. 2, no. 6, pp. 542-549, 2013.

[14] A. Croteau and P. Li, "Critical success factors of CRM technological initiatives,” Can. J. Adm. Sci. Can. des Sci. l'Administration, vol. 20, no. 1, pp. 21-34, 2003.

[15] R. P. U. Beijerse, "Questions in knowledge management: Defining and conceptualising a phenomenon," J. Knowl. Manag., vol. 3, no. 2, pp. 94-110, 1999.

[16] C. J. Stefanou, C. Sarmaniotis, and A. Stafyla, "CRM and customer-centric knowledge management: an empirical research," Bus. Process Manag. J., vol. 9, no. 5, pp. 617-634, 2003.
[17] A. Mohammed and B. Rashid, "Customer relationship management $(\mathrm{CRM})$ in hotel industry: A framework proposal on the relationship among CRM dimensions, marketing capabilities, and hotel performance," Int. Rev. Manag. Mark., vol. 2, no. 4, pp. 220-230, 2012.

[18] R. Chalmeta, "Methodology for customer relationship management," $J$. Syst. Softw., vol. 79, no. 7, pp. 1015-1024, Jul. 2006.

[19] C. D. Ńu and H. Hălmăjan, "The effect of organizational readiness on CRM and business performance," Int. J. Comput., vol. 5, no. 1, pp. 106-114, 2011.

[20] T. S. H. Teo, P. Devadoss, and S. L. Pan, "Towards a holistic perspective of customer relationship management (CRM) implementation: A case study of the Housing and Development Board, Singapore," Decis. Support Syst., vol. 42, no. 3, pp. 1613-1627, Dec. 2006.

[21] R. Samizadeh and N. Nikoo, "Checking effective factors and presenting the framework for customer relationship management in hospitals in Iran," Eng. Manag. Res., vol. 1, no. 2, pp. 163-172, Oct. 2012.

[22] M. Bahrami, M. Ghorbani, and S. M. Arabzad, "Information technology (IT) as an improvement tool for customer relationship management (CRM)," Procedia-Social Behav. Sci., vol. 41, pp. 59-64, 2012.

[23] A. Lindgreen, R. Palmer, J. Vanhamme, and J. Wouters, "A relationship-management assessment tool: Questioning, identifying, and prioritizing critical aspects of customer relationships," Ind. Mark. Manag., vol. 35, no. 1, pp. 57-71, Jan. 2006.

[24] I. J. Chen and K. Popovich, "Understanding customer relationship management (CRM): People, process and technology," Bus. Process Manag. J., vol. 9, no. 5, pp. 672-688, 2003.

[25] J. Radcliffe, "Eight building blocks of CRM: A framework for success," Gartner research, 2001, vol. 13, pp. 1-4.

[26] A. Keramati, H. Samadi, S. Nazari-Shirkouhi, and N. Askari, "Identifying and prioritising critical success factors for CRM implementation: a case study," Int. J. Electron. Cust. Relatsh. Manag., vol. 6, no. 3-4, pp. 235-256, 2012.

[27] J. F. Hair, W. C. Black, B. J. Babin, R. E. Anderson, and R. L. Tatham, "Multivariate data analysis (Vol. 6)." Upper Saddle River, NJ: Pearson Prentice Hall, 2006.

[28] M. A. T. Almotairi, "Evaluation of the implementation of CRM in developing countries," Brunel University Brunel Business School PhD Theses, 2010.

[29] K. Rababah, H. Mohd, and H. Ibrahim, "Customer relationship management (CRM) processes from theory to practice: The pre-implementation plan of CRM system," Int. J. e-Education, e-Business, e-Management e-Learning, vol. 1, no. 1, pp. 22-27, 2011.

[30] M. Anshari, A. Al-Mudimigh, and M. Aksoy, "CRM initiatives of banking sector in Saudi Arabia," Int J Comput Internet Manag, vol. 19, no. 1, pp. 51-56, 2009.

Sara A. Al-Rashed is a lecturer in the Department of Information System with Al-Imam Muhammad bn Saud Islamic University, Riyadh, Saudi Arabia. Her research interests include customer relationship management, systems analysis and data mining. 